\title{
The Selenga River delta: a geochemical barrier protecting Lake Baikal waters
}

\author{
Sergey Chalov ${ }^{1}$ (1) $\cdot$ Josefin Thorslund $^{2} \cdot$ Nikolay Kasimov $^{1} \cdot$ Denis Aybullatov $^{1} \cdot$ \\ Elena Ilyicheva $^{3}$ - Daniel Karthe ${ }^{4} \cdot$ Alexey Kositsky $^{1} \cdot$ Mikhail Lychagin $^{1}$. \\ Jeff Nittrouer $^{7}$ • Maxim Pavlov ${ }^{3} \cdot$ Jan Pietron $^{2} \cdot$ Galina Shinkareva $^{1}$. \\ Mikhail Tarasov $^{1} \cdot$ Endon Garmaev $^{5} \cdot$ Yosef Akhtman $^{6} \cdot$ Jerker Jarsjö $^{2}$
}

Received: 29 September 2015/ Accepted: 28 May 2016

(C) Springer-Verlag Berlin Heidelberg 2016

\begin{abstract}
The protection of Lake Baikal and the planning of water management measures in the Selenga River Basin require a comprehensive understanding of the current state and functioning of the delta's ecosystem and hydrogeochemical processes. This is particularly relevant in light of recent and expected future changes involving both the hydrology and water quality in the Lake Baikal basin causing spatiotemporal changes in water flow, morphology, and transport of sediments and metals in the Selenga River delta and thus impacting on delta barrier functions. The central part of the delta had been characterized by sediment storage, especially along the main channels, causing a continuous lift of the delta surface by about $0.75 \mathrm{~cm} /$ year $^{-1}$. Theses morphological changes have a significant impact on
\end{abstract}

Electronic supplementary material The online version of this article (doi:10.1007/s10113-016-0996-1) contains supplementary material, which is available to authorized users.

Sergey Chalov

hydroserg@mail.ru

1 Faculty of Geography, M. V. Lomonosov Moscow State University, Leninskie Gory 1, Moscow, Russia 119911

2 Department of Physical Geography and Quaternary Geology, Stockholm University, 10691 Stockholm, Sweden

3 Institute of Geography SB RAS, Ulan-Batorskaya, 1, Irkutsk, Russia 664033

4 Helmholtz Centre for Environmental Research (UFZ), Brückstraße 3a, 39114 Magdeburg, Germany

5 Baikal Institute of Nature Management SB RAS, ul Sakhayanovoy, 6, Ulan-Ude, Russia 670047

6 Swiss Federal Institute of Technology Lausanne (EPFL), GR A2434, Station 2, 1015 Lausanne, Switzerland

7 Department of Earth Science, Rice University MS 126, 1892 , 77251 Houston, TX, USA hydrological conditions, with historical shifts in the bulk discharge from the left to the right parts of the delta which is distinguished by a relatively high density of wetlands. Regions with a high density of wetlands and small channels, in contrast to main channel regions, show a consistent pattern of considerable contaminant filtering and removal (between 77 and $99 \%$ for key metals), during both high-flow and low-flow conditions. The removal is associated with a significant concentration increase (2-3 times) of these substances in the bottom sediment. In consequence, geomorphological processes, which govern the partitioning of flow between different channel systems, may therefore directly govern the barrier function of the delta.

Keywords Delta - Lake Baikal · Geochemical barrier . Sediment loads $\cdot$ Wetlands

\section{Introduction}

River systems function as a "pipeline network" for water, sediment, and chemical transport. However, many pathways of sediment and metals' transport do not lead directly from a source to the recipient water body, but to intermediate storages that are alternately filled and depleted. The sharpest changes occur within geochemical barriers where physical or chemical gradients alter transport conditions, resulting in a substantial accumulation of elements (Perel'man 1986).

River deltas typically form such geochemical barriers or parts of so-called marginal filters at rivers' outlets. At the global scale, river deltas form a narrow belt where a variety of physical, chemical, and biological transformations may lead to the removal of up to $90-95 \%$ of suspended particles and $20-40 \%$ of dissolved substances (Lisitzin 1995). The filtering function of the river deltas encompasses 
gravitational sedimentation, flocculation, and biofiltration (Sholkovitz 1976). These functions are influenced by various characteristics of the river deltas, such as their size, morphology, river channelization, and vegetation. The efficiency of the filtering function of sediment and contaminant flows that enter river deltas is critical for the water quality of the downstream water body (e.g., Meybeck and Vörösmarty 2005), since delta areas are the final buffer zone before water enters the receiving basin (Ajao and Anurigwo 2002; Buschmann et al. 2007; Chatterjee et al. 2009; Lychagin et al. 2015; Santschi et al. 2001; Shaban et al. 2010). These filtering and retention functions of the geochemical barriers highlight the need for the research in the outlets of the rivers experiencing increased human pollution.

In this regard, one of the most ancient and largest freshwater deltas of the world-the Selenga River deltadeserves special attention as far as it works as a barrier between the world's largest freshwater lake by volume (Lake Baikal) and its main tributary (the Selenga River). The Selenga River delta receives high sediment and metal loads, which were previously detected in the water and sediments of the Selenga River system as well as in the floodplains' soils and groundwater (Brumbaugh et al. 2013; Chalov et al. 2012; Chebykin et al. 2010, 2012; Inam et al. 2011; Nadmitov et al. 2014; Pfeiffer et al. 2015; Stubblefield et al. 2005; Thorslund et al. 2012). Of particular importance for the delta are the hydrological impacts resulting from the construction and operation of the Irkutsk dam in 1959. When put into operation, this dam caused high and intensive flooding of the Selenga River delta, including a complete inundation during the periods when the Lake Baikal's water level increased the most (Ilyicheva 2008).

Due to the mentioned human alterations and dynamic hydroclimatic changes in the region (Törnqvist et al. 2014), the filtering function of the delta is likely to vary in time and space, e.g., with changing conditions of the flow partitioning between the delta's branches and migration of sediment plumes through the delta under increasing discharge conditions. The input load of contaminants, which can influence barrier effects, is also dynamic (Chalov et al. 2013; Thorslund et al. 2016). To the best of our knowledge, only few studies (Aynbund et al. 1975; Potemkina and Fialkov 1993) examined sediment retention in the region, whereas no quantitative assessment of the geochemical barrier function has ever been done. Hence, the objectives of this study were as follows:

- To synthesize data on morphological changes and the long-term effects of dynamic flow and sediment transport processes within the delta, which serve as indicators for hydrological changes;
- To quantify spatial patterns in dispersal of sediment and metals within the delta during different hydrological phases, and relate them to patterns of flow partitioning among the bifurcating channel network.

- To identify the transition zones that exist within the delta area, determine the relative concentrations of elements transported in particulate and dissolved forms, and provide insight into the function of the Selenga River delta and its wetlands for filtering sediment and metal inflows into the Lake Baikal.

\section{Site description}

The Selenga River's $447.060 \mathrm{~km}^{2}$ drainage basin comprises $82 \%$ of Lake Baikal Basin (Garmaev and Khristoforov 2010). Located north of the city of Ulan Ude and just before the outlet of the Selenga into Lake Baikal, the Selenga River delta constitutes the largest $\left(600 \mathrm{~km}^{2}\right)$ wetland region in East Siberia. The elevation of the delta is less than $2 \mathrm{~m}$ above the average water level of Lake Baikal. The delta contains three main distributary systems (sectors): the Lobanovskiy channel system (right), the Sredneustievskiy channel system (central), and the Selenginskiy channel system (left), named after the largest channels of the dispersal system (Fig. 1). A significant part of the delta is swamped and possesses a great number of tiny lakes. Altogether, the delta comprises more than 30 distributaries of various sizes. The territory is regularly impounded during the high water period (April-October). Spring floods in the delta start at the end of March and end in June (the total duration is up to 110 days). The international relevance of Lake Baikal as a UNESCO World Natural Heritage site and the Selenga River delta as a unique ecosystem that acts as a natural filter for Lake Baikal have led to several multinational research projects in the region (Karthe et al. 2015b).

\section{Methods of data collection and analysis}

The present study is based on available hydrological, geochemical, biological, land-use, and land-cover information, which is partly based on remote sensing data.

\section{Water discharge measurements}

To investigate changes in flow partitioning along the study reach, we assembled available water discharge measurements. The Selenga River delta has no regular gauging stations. The first complete survey on flow partitioning among delta branches was conducted in the 


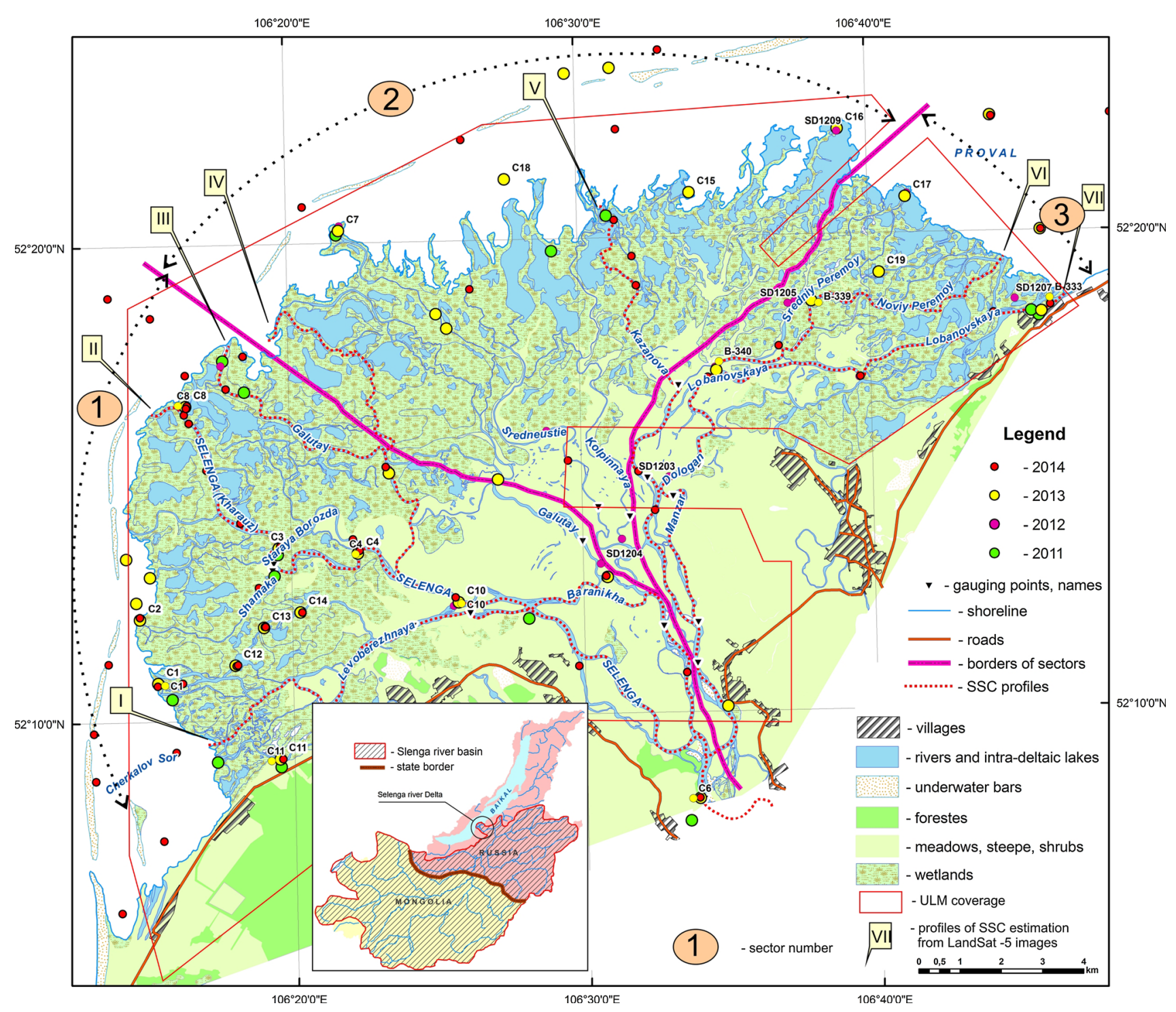

Fig. 1 Selenga River drainage basin and the Selenga River deltasampling sites and sectors. Numbers C1..C19, B-... and SD-... indicate sampling sites delta during the field campaign in 2011-2014.
Distributary sector numbers: 1-Selenginsky (left); 2-Sredneustievskiy (central); 3-Lobanovsky (right) (\%) early 1980s by the Institute of Limnology of the Siberian Branch of the Russian Academy of Sciences (Potemkina 1995). In 1990, the estuarial station of Roshydromet became operational. Since 2003, irregular discharge measurements (mainly during the summer-autumn period) were collected by the V.B. Sochava Institute of Geography and Limnological Institute of the Siberian Branch of the Russian Academy of Sciences. Since 2011, water and sediment discharge measurements have been taken by the Faculty of Geography of Lomonosov Moscow State University and Stockholm University, both in summer (2011-2015) and during the winter ice cover (January and March 2015) seasons. Due to changing location of the discharge measurements, assembled data were mostly used to quantify water discharge partitioning between the main Selenga River delta sectors (Fig. 1). In all cases, discharge $\left(Q, \mathrm{~m}^{3} \mathrm{~s}^{-1}\right)$ measurements were taken using velocity current meters deployed from boats, or through the ice during winter field campaigns. The relative discharges $Q_{i} \%$ in the certain distributaries (sectors) of delta were calculated as:

$Q_{i}, \%=Q_{i} / Q_{0} \times 100 \%$

where $Q_{i}$ is the discharge (in $\mathrm{m}^{3} \mathrm{~s}^{-1}$ ) in an individual distributary and $Q_{0}$ is the total discharge (in $\mathrm{m}^{3} \mathrm{~s}^{-1}$ ) of the Selenga prior to entering the delta. 


\section{Delta sampling and analysis}

Geochemical data were obtained during field campaigns in 2012 and 2013 (by Lomonosov Moscow State University and Stockholm University). Water and bottom sediments samples were collected from various locations within the Selenga River delta during field campaigns in September 2012 and 2013 and July 2013 (over 30 sampling sites). Information on the sampling locations is given in Fig. 1. Water was collected from just below the air-water interface into rinsed plastic polypropylene bottles $(500 \mathrm{ml})$ deployed from a boat. Sampled water was then transferred into two high-density polypropylene test tubes $(10 \mathrm{ml})$, where one sample was filtered (through a sterile $0.20-\mu \mathrm{m}$ pore membrane filter, which had been prewashed with sample water) and another sample remained unfiltered. The test tubes were sterile as well as rinsed with the sampled water before collecting the sample. Three replicates of both the filtered and unfiltered samples were collected, and all were acidified $(1 \%)$ with concentrated $\mathrm{HNO}_{3}(65 \%)$ for preservation.

All samples (suspended and streambed sediments and filtered water) were analyzed for 62 elements by inductively coupled plasma mass spectrometry ICP-MS (ICP-AES) using a semiquantitative mode and a tenfold automated dilution during the analysis. Particular attention in the following work was given to widely distributed elements (according to Chalov et al. 2015), namely Al, As, Cd, Cr, $\mathrm{Cu}, \mathrm{Fe}, \mathrm{Mn}, \mathrm{Mo}, \mathrm{Pb}, \mathrm{Sr}, \mathrm{V}$, and $\mathrm{Zn}$. Elemental analyses were conducted on the filtered samples without additional treatment. For a fully quantitative analysis, the instrument was calibrated with a series of known standards for each element. Corrections were applied for potential interferences, and more comprehensive quality assurance/control measures were performed for each element. The sample analyses were performed at Stockholm University and in N.M. Fedorovsky Russian Scientific Research Institute of Mineral Resources (Russia), using a micro-concentric nebulizer and, in some cases to obtain better detection limits when needed, an ultrasonic nebulizer, CETAC USN U5000AT+. All metals which were discovered in filtered water samples were considered as a dissolved form and elements which were revealed in suspended sediments settled on membrane filters, as a suspended form. The metal concentrations $\left(\mathrm{mg} \mathrm{kg}^{-1}\right)$ in bottom sediments were compared with concentrations in the upper continental crust (Cucc) according to Rudnick and Gao (2003).

The load of heavy metals in dissolved form $\left(W_{d}\right.$, $\mathrm{kg} \mathrm{day}^{-1}$ ) for each element $i$ was calculated with the equation $W_{d i}=Q \times C_{d i}$ where $Q$ is the water discharge $\left(\mathrm{m}^{3} \mathrm{~s}^{-1}\right)$ and $C_{d i}$ is the concentration of $i$-element in water $\left(\mathrm{g} \mathrm{m}^{-3}\right)$. Likewise, the load of heavy metals in suspended form $\left(W_{s i}, \mathrm{~kg} \mathrm{day}^{-1}\right)$ for each element $i$ was calculated with the equation $W_{s i}=\mathrm{SSL} \times C_{s i}$ where $S S L$ is the suspended sediment load $\left(\mathrm{kg} \mathrm{s}^{-1}\right)$ and $C_{s i}$ is the concentration of $i$-element in suspended sediment $\left(\mathrm{g} \mathrm{m}^{-3}\right)$.

\section{GIS and remote sensing data}

Changes in elevations of the Selenga River delta for the past 46 years were estimated using toposheets dated by 1952 and 1998. These maps represent the periods before and after the Selenga River delta was partly inundated by waters from Lake Baikal upon completion of the Irkutsk dam in 1959. The maps were digitized in ArcGIS to create digital elevation models (DEMs). The hypsometric models of the subaerial delta for these periods were developed using a triangulated irregular network (TIN) based on the DEMs, including absolute benchmark of the sea level and the Lake Baikal water level (Fig. 2). Hypsometric levels were considered at a $0.5 \mathrm{~m}$ step resolution, which corresponded to the accuracy of topographic maps.

Analysis of changes in flow partitioning of the Selenga River delta was based on the processing of digital remote sensing data representing the last 37 years (SPOT-4, SPOT-5, and Landsat). The in-channel water discharge was calculated from remotely sensed water surface widths in the delta branches. Water surface widths measured from digital images were coupled with measured discharge data from at a gauging station located upstream of the Selenga River delta, which yielded a correlation of $R^{2}=0.76$ :

$Q_{0}=37.21 B_{0}^{0.2164}$

where $B_{0}$ is the channel width (in m) obtained from the cross section at the gauging station using Landsat $(15 \mathrm{~m}$ resolution) and SPOT-4 (8 m resolution), and $Q_{0}$ is the measured discharge (in $\mathrm{m}^{3} \mathrm{~s}^{-1}$ ) at the gauging station. Equation (1) was used to calculate discharges in the Selenga River delta branches using values of average channel width $B_{i}$ based on the assumption that:

$\left(B_{i} / B_{0}\right)^{2}=Q_{i} / Q_{0}$,

where $Q_{i}$ are water discharges $\left(\mathrm{m}^{3} \mathrm{~s}^{-1}\right)$ in the analyzed branches.

To estimate longitudinal changes in suspended sediment concentration (SSC) within the seven selected branches of the Selenga River delta (I-VII, Fig. 1) for periods of different hydrological conditions, a method presented by Doxaran et al. (2002) was used. A regression equation was obtained by comparing 2011 Landsat 5 (red zone) with field measurements of SSC $\left(R^{2}=0.87\right)$

$\mathrm{SSC}=801.31 \rho-21.98$,

where SSC is the suspended sediment concentration $\left(\mathrm{g} \mathrm{m}^{-3}\right)$, and $\rho$ is the reflectance for each cell. These analyses were performed for eleven Landsat images 

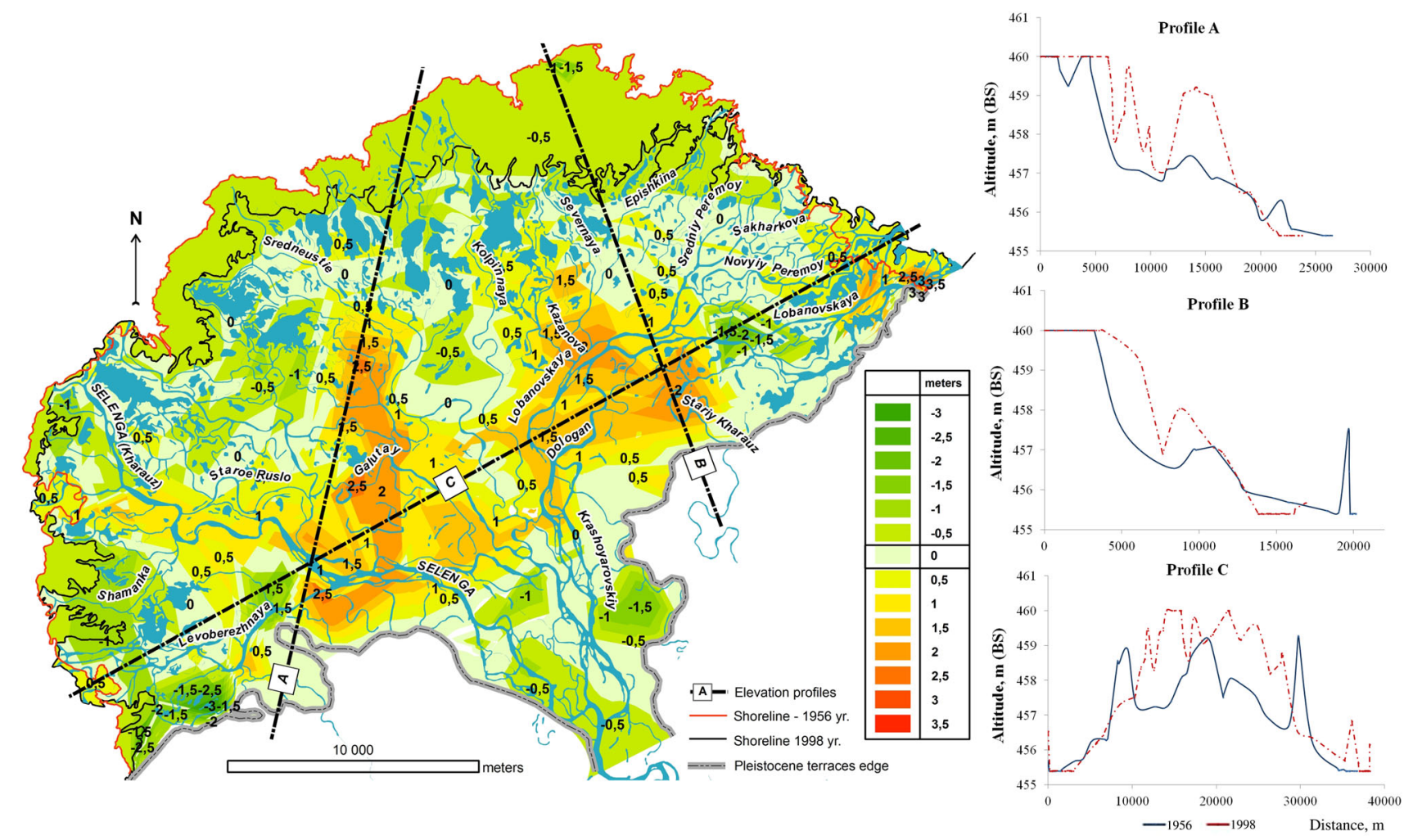

Fig. 2 Changes in elevation of the delta surface between 1956 and 1998

(Landsat-5, Landsat-7, and Landsat-8) for summer flood conditions $\quad(17.09 .1990, \quad 02.06 .1992, \quad 23.07 .1999$, 13.08.2001, 04.08.2003, 08.07.2005, 21.07.2013) and low water period $(08.06 .1994, \quad 15.08 .2007,08.09 .2010$, 20.07.2015). The longitudinal changes in suspended sediment concentration for the seven selected branches were further used to calculate suspended sediment retention SSR (\%) for the three different distributary sections of the delta (left, central, and right). The following formula was used:

$\mathrm{SSR}=\left(\mathrm{SSL}_{\mathrm{up} i}-\mathrm{SSL}_{\mathrm{down} i}\right) / \mathrm{SSL}_{\mathrm{up} i}$

where $\mathrm{SSL}_{\mathrm{up} i}$ is the suspended sediment load $\left(\mathrm{kg} \mathrm{s}^{-1}\right)$ upstream of a distributary system $i$ and $\mathrm{SSL}_{\text {down } i}$ is the suspended sediment load $\left(\mathrm{kg} \mathrm{s}^{-1}\right)$ in the outlets of the distributary system $i$. The SSL $_{\text {down }}$ was estimated by multiplying water discharges $Q_{i}$ in each of distributary sectors with average SSC at the outlets of the sector branches determined from satellite imageries. $\mathrm{SSL}_{\mathrm{up}}$ in each sector was calculated proportionally to flow partitioning between sectors assuming equal SSC in the upper part of the delta during survey (varying from $12 \mathrm{~g} \mathrm{~m}^{-3}$ on 20.07.2015 to $70 \mathrm{~g} \mathrm{~m}^{-3}$ on 13.08.2001). For the calculation of the total (suspended and bed) sediment load retention TSR (\%), we assumed that all bed load (gravel and sand) is terminated in the delta and that the bed load explains around $50 \%$ of the total sediment load for the upper part of Selenga River delta (Chalov et al. 2015).
The remote sensing data were obtained in 2013-2015 using group of cameras mounted on ultralight aircraft using remote sensing platform (EPFL, Switzerland) (Akhtman et al. 2014). The camera system included the Headwall Photonics Micro Hyperspec VNIR sensor (250 bands, $400-860 \mathrm{~nm}$ ) as the main instrument, and the Gamaya hyperspectral camera, developed at EPFL (16 bands, 400-900 nm) as an experimental part, and two DSLR cameras (Sony-Nex5r) with RGB and NIR filters. For image georeferencing, GPS and inertial navigation system were installed on the aircraft. During the July 2013 and August 2014 field campaigns, about 40 flights were carried out and almost the whole area of the Selenga River delta was covered. In further analyses, we used the hyperspectral and DSLR data obtained in 2014. Data were processed with geometric and atmospheric corrections. Image mosaics were created using software Agisoft Photoscan and developed in the TOPO laboratory (EPFL, Switzerland) software HypOS.

\section{Results}

\section{Changes in delta morphology}

Significant changes in morphology of the Selenga River delta were observed for period 1952-1998 (Fig. 2). The middle part of delta was characterized by sediment 
aggradation, especially along the main channels. This aggradation has led to the lift of the delta surface from $457.0 \mathrm{~m}$ in 1956 to $457.8 \mathrm{~m}$ in 1998. Maximal rise of the surface was in middle parts of central and right sectors within the largest bifurcation nodes. Additional data show channel migration in the upper part of the delta reaching $75 \mathrm{~m}$ for the left bank and $100 \mathrm{~m}$ for the right bank over the last 10 years. We estimated the average speed of bank erosion to be about $6 \mathrm{~m} \mathrm{year}^{-1}$. Thus, the aggradation in the middle part of the delta could be related to the channel migration processes. Sediment accumulation in the river channels and floodplain caused changes in the channel network planar location. Zones of surface lowering were predominantly related to the peripheral part of the delta central sector.

Furthermore, different magnitudes of shifts of the delta edges were observed. Constant delta retrogradation by 3-5 km until 1998 was observed in the central part (black and red borders, Fig. 2). Recent growth of the delta area occurs due to sediment filling of some water bodies between the edge of the subaerial delta and a chain of bordering barrier bars. In the right sector, historical delta progradation is $30-40 \mathrm{~m}$ year $^{-1}$. In many cases, branches were straightened. Length of the shoreline does not change against the overall progradation.

\section{Patterns of flow partitioning}

The morphological changes within the delta have a significant impact on hydrological conditions and flow partitioning within the three sectors (Table 1). Previous studies (Potemkina 1995) have reported the dominant role of the left sector in terms of water flow (up to 55-65\% of water when the Selenga's total water discharge is under $2000 \mathrm{~m}^{3} \mathrm{~s}^{-1}$ and up to $95 \%$ during winter period) in the early 1970s. Later, changes in delta morphology have led to a decline in flow partitioning to the left sector (so that now it conveys up to $35 \%$ of the total summer flow) and a greater part of the water entering the right sector (increase by $12 \%$ ) and the central sector (50\%) (Fig. 3). During an exceptional low discharge event measured at the apex of the delta $\left(72.0 \mathrm{~m}^{3} \mathrm{~s}^{-1}\right)$ during February $2015,57 \%$ of the water flow was conveyed through the left sector, whereas

Table 1 Observed patterns in water partitioning along delta branches (sectors)

\begin{tabular}{|c|c|c|c|c|c|}
\hline Dates & $\begin{array}{l}\text { Water discharge in Selenga } \\
\left(\mathrm{m}^{3} \mathrm{~s}^{-1}\right)\end{array}$ & $\begin{array}{l}\text { Selenginskiy } \\
\text { (left) }(\%)\end{array}$ & $\begin{array}{l}\text { Sredneustievskiy } \\
\text { (central) }(\%)\end{array}$ & $\begin{array}{l}\text { Lobanovsky } \\
\text { (right) }(\%)\end{array}$ & Sources \\
\hline 21.06 .1975 & 1610 & 67 & 11 & 22 & $\begin{array}{l}\text { Calculated from } \\
\text { Landsat-1 }\end{array}$ \\
\hline Summer 1981 & 599 & 61 & 9 & 30 & Potemkina (1995) \\
\hline Summer 1984 & 1110 & 56 & 10 & 34 & Potemkina (1995) \\
\hline Summer 1986 & 1041 & 55 & 10 & 35 & Potemkina (1995) \\
\hline 30.09 .1989 & 1135 & 71 & 4 & 25 & $\begin{array}{l}\text { Calculated from } \\
\text { Landsat- } 4,5\end{array}$ \\
\hline 1994 (low water) & 800 & 58 & 10 & 32 & Field data \\
\hline 1994 (flood) & 4000 & 45 & 14 & 41 & Field data \\
\hline 11.09 .2000 & 1891 & 60 & 9 & 31 & $\begin{array}{l}\text { Calculated from } \\
\text { Landsat-5 }\end{array}$ \\
\hline 18.09.2002 & 130 & 52 & 11 & 37 & $\begin{array}{l}\text { Calculated from } \\
\text { Landsat-5 }\end{array}$ \\
\hline July 2006 & 1820 & 27 & 19 & 47 & Field data \\
\hline $\begin{array}{l}\text { August-September, } \\
2006\end{array}$ & 1050 & 34 & 27 & 39 & Field data \\
\hline Summer, 2007 & 882 & 40 & 15 & 44 & Field data \\
\hline Autumn, 2009 & 1050 & 40 & 17 & 43 & Field data \\
\hline July 2011 & 1442 & 42 & 11 & 47 & Field data \\
\hline 28.07.2012 & 2717 & 30 & 22 & 48 & Field data \\
\hline 29.09 .2012 & 992 & 45 & 15 & 40 & Field data \\
\hline 05.07 .2013 & 1697 & 36 & 19 & 45 & Field data \\
\hline 18.07.2013 & 1482 & 45 & 19 & 36 & Field data \\
\hline $10-14.09 .2013$ & 2794 & 28 & 20 & 52 & Field data \\
\hline 19.07.2014 & 1166 & 48 & 17 & 35 & Field data \\
\hline $\begin{array}{l}27.01-05.02 .2015 \text { (ice } \\
\text { cover) }\end{array}$ & 76 & 57 & 17 & 26 & Field data \\
\hline
\end{tabular}


Fig. 3 Seasonal changes in relative discharges $\left(Q_{i}, \%\right)$ in left (I), central (II), and right (III) Selenga delta sectors for 2002-2013 (1-blue points) in comparison with 1975-2000 (2—orange points). $Q_{0}$ - total discharge in the Selenga river $\left(\mathrm{m}^{3} \mathrm{~s}^{-1}\right)$
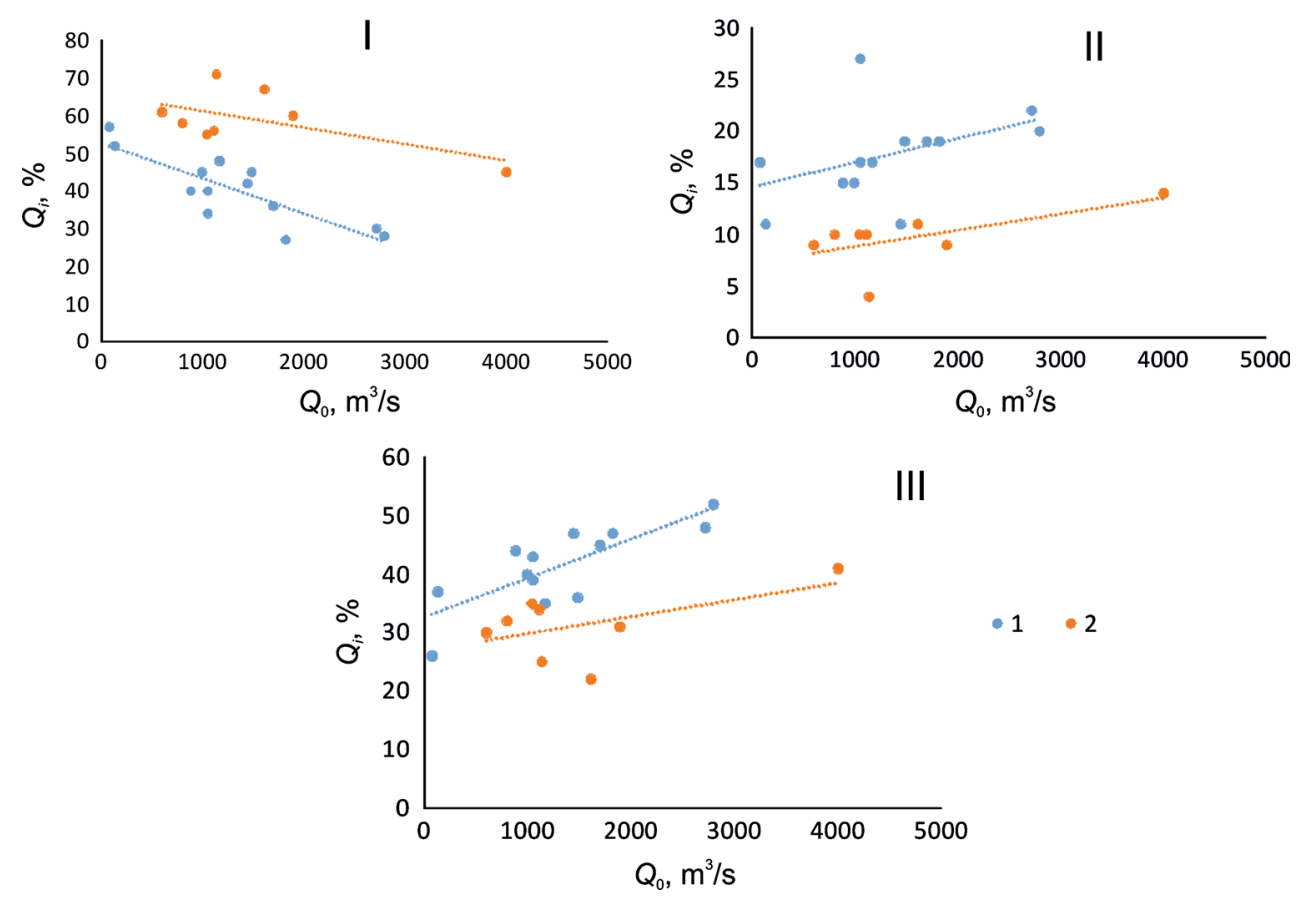

the amount of water in the right sector was the lowest among the observations, measuring $19.4 \mathrm{~m}^{3} \mathrm{~s}^{-1}$ (26\% of the discharge). For the most recent field summer campaigns (2012-2013), 2013 was a high-flow year, with discharges up to three times greater than compared to the low-flow period of 2012 (2794 and $992 \mathrm{~m}^{3} \mathrm{~s}^{-1}$, respectively).

\section{Transport and storage of sediments and heavy metals}

Field data (Fig. 1) obtained during various hydrological seasons revealed relatively constant values of sediment loads in the upper part of the delta, and an abrupt fall in SSC in the lower $5-10 \mathrm{~km}$ of the delta before the lake. During the 2013 field campaign, SSC varied from 30 to $35 \mathrm{~g} \mathrm{~m}^{-3}$ in the Selenga main stream upstream of the delta, to $3-5 \mathrm{~g} \mathrm{~m}^{-3}$ in the main branches and $1-2 \mathrm{~g} \mathrm{~m}^{-3}$ in small streams at wetland pond outlets. The longitudinal changes in SSC along the main branches (I-VII, Fig. 1) for summer flood conditions under water discharges $Q_{0}$ between $1230 \mathrm{~m}^{3} \mathrm{~s}^{-1}$ (23.07.1999) and $3000 \mathrm{~m}^{3} \mathrm{~s}^{-1}$ (17.09.1990) and low water periods under water discharges $Q_{0}$ between $706 \mathrm{~m}^{3} \mathrm{~s}^{-1}$ (20.07.2015) and $1020 \mathrm{~m}^{3} \mathrm{~s}^{-1}$ (08.06.1994) revealed in most cases particles retention within channel (Fig. 4). The most significant SSC decline was observed in the right branches with a total reduction in SSC up to $50 \%$ in 2010 (from 14 to $7 \mathrm{~g} \mathrm{~m}^{-3}$ ) during low water and flood conditions in 1990 (from 27 to $13 \mathrm{~g} \mathrm{~m}^{-3}$ ). Pronounced declines of SSC are commonly observed at the outlet branches near Lake Baikal, in particular along the downstream $10 \mathrm{~km}$ of branches III (from 1999 to 2013), IV (from 1990 to 2013), V (from 1990 to 1999 and 2007, 2010), and VII (1990, 1992, 2001, 2005, 2010). Modest increases of SSC along profiles VI and VII (2013) have also been seen. Such increases were also reported along all profiles in 2015 (Table 2).

Suspended sediment retention (SSR) estimates show that between 10 and $33 \%$ of the suspended sediment load are stored within the delta. In most cases, relative values of sediment retention (SSR, \%) were higher in the central or right delta sectors than in the left delta sector. In absolute terms, due to differences in flow partitioning between distributaries (channel size), the difference between the SSLup and SSLdown $\left(\Delta \mathrm{SSL}, \mathrm{kg} \mathrm{s}^{-1}\right)$ was higher in the left and right sectors than in the central sector. The estimate of total (bed and suspended load) sediment retention suggests that $42-68 \%$ of the total load is retained in the delta (Table 2).

The total concentration of most metals in the Selenga River delta is dominated by the suspended phase. The average partitioning of considered metals along some of the large and small delta channels is shown in the Supplementary information (SI). Overall, $\mathrm{Al}, \mathrm{Cd}, \mathrm{Cr}, \mathrm{Fe}, \mathrm{Mn}$, and $\mathrm{V}$ are dominated by their suspended phases, whereas $\mathrm{As}, \mathrm{Cu}, \mathrm{Mo}, \mathrm{Pb}$, and $\mathrm{Zn}$ prevail in the more mobile dissolved phase. These general patterns are valid for both the low-flow conditions and high-flow conditions (see SI).

In the larger channels, there was no observable decrease in total concentrations of metals (see SI), neither during the low-flow year of 2012 nor during the high-flow year of 

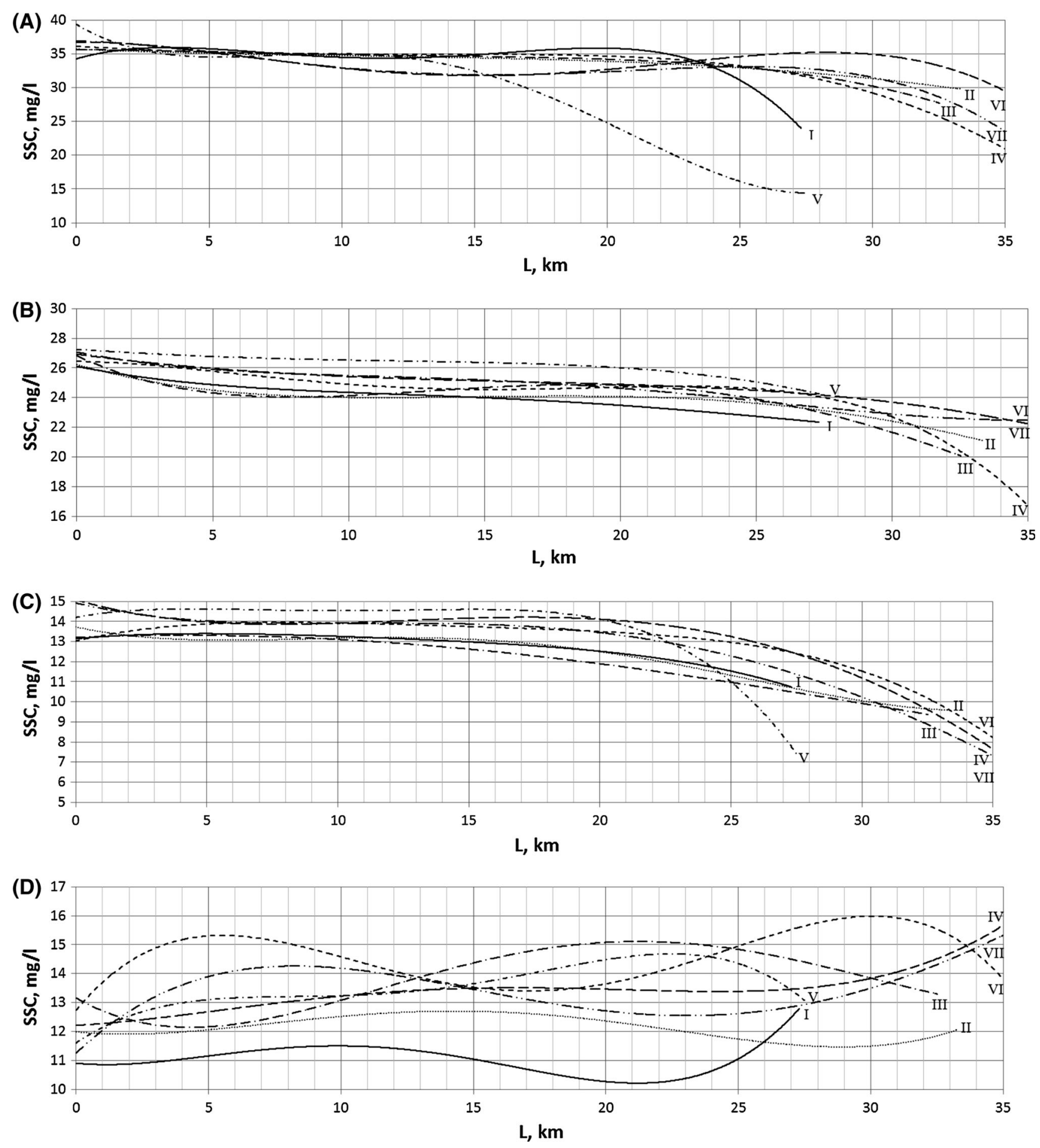

$$
\text { - I -...... II - - III - - IV - - - V - - - VI -..-VII }
$$

Fig. 4 Longitudinal changes in SSC along main branches located in the left (I, II), central (III, IV, and V), and right (VI and VIII) sectors of Selenga delta (a 02.06.1992, $Q_{0}=1430 \mathrm{~m}^{3} \mathrm{~s}^{-1}$, b 13.08.2001,

$Q_{0}=1850 \mathrm{~m}^{3} \mathrm{~s}^{-1}$, c $08.09 .2010, Q_{0}=983 \mathrm{~m}^{3} \mathrm{~s}^{-1}, \mathbf{d}$ 20.07.2015, $Q_{0}=706 \mathrm{~m}^{3} \mathrm{~s}^{-1}$ )

2013. Concentrations were stable or showed slight increases from the most upstream to the most downstream part. There are overall higher concentrations in measurements taken in 2012 than in 2013, with up to one order of magnitude (values reaching about $6500 \mu \mathrm{g}^{-1}$ for key metals such as $\mathrm{Al}$ and $\mathrm{Fe}$ ). 
Table 2 Calculated suspended sediment load decrease ( $\Delta$ SSL, $\mathrm{kg} \mathrm{s}^{-1}$ ), suspended sediment retention (SSR, \%), and total (bed and suspended load) sediment retention (TSR, \%) along main sectors of the Selenga River delta

\begin{tabular}{|c|c|c|c|c|}
\hline Sector & Left (Selenginsky) & Central (Sredneustievskiy) & Right (Lobanovsky) & Total \\
\hline \multicolumn{5}{|c|}{$17.09 .1990, Q_{0}=3000 \mathrm{~m}^{3} \mathrm{~s}^{-1}$} \\
\hline$\Delta \operatorname{SSL}\left(\mathrm{kg} \mathrm{s}^{-1}\right)$ & 10.8 & 3.5 & 13.1 & 27.3 \\
\hline $\operatorname{SSR}(\%)$ & 22.2 & 42.6 & 53.7 & 33.70 \\
\hline TSR $(\%)$ & 61.11 & 71.30 & 76.85 & 66.85 \\
\hline \multicolumn{5}{|c|}{$02.06 .1992, Q_{0}=1430 \mathrm{~m}^{3} \mathrm{~s}^{-1}$} \\
\hline$\Delta \operatorname{SSL}\left(\mathrm{kg} \mathrm{s}^{-1}\right)$ & 5.4 & 1.7 & 2.9 & 10.0 \\
\hline $\operatorname{SSR}(\%)$ & 18.2 & 45.5 & 21.2 & 21.24 \\
\hline TSR $(\%)$ & 59.09 & 72.73 & 60.61 & 60.62 \\
\hline \multicolumn{5}{|c|}{$08.06 .1994, Q_{0}=1020 \mathrm{~m}^{3} \mathrm{~s}^{-1}$} \\
\hline$\Delta \operatorname{SSL}\left(\mathrm{kg} \mathrm{s}^{-1}\right)$ & 3.0 & 0.5 & 0.7 & 4.2 \\
\hline $\operatorname{SSR}(\%)$ & 18.0 & 30.0 & 10.0 & 16.60 \\
\hline TSR $(\%)$ & 59.00 & 65.00 & 55.00 & 58.30 \\
\hline \multicolumn{5}{|c|}{$23.07 .1999, Q_{0}=1230 \mathrm{~m}^{3} \mathrm{~s}^{-1}$} \\
\hline$\Delta \operatorname{SSL}\left(\mathrm{kg} \mathrm{s}^{-1}\right)$ & 6.9 & 1.1 & 3.3 & 11.3 \\
\hline $\operatorname{SSR}(\%)$ & 17.8 & 27.1 & 18.6 & 18.69 \\
\hline TSR $(\%)$ & 58.90 & 63.56 & 59.32 & 59.35 \\
\hline \multicolumn{5}{|c|}{ 13.08.2001, $Q_{0}=1850 \mathrm{~m}^{3} \mathrm{~s}^{-1}$} \\
\hline$\Delta \operatorname{SSL}\left(\mathrm{kg} \mathrm{s}^{-1}\right)$ & 4.66 & 5.27 & 12.49 & 22.42 \\
\hline $\operatorname{SSR}(\%)$ & 10.0 & 21.4 & 21.4 & 17.31 \\
\hline TSR (\%) & 55 & 60.71 & 60.71 & 58.66 \\
\hline \multicolumn{5}{|c|}{$04.08 .2003, Q_{0}=1320 \mathrm{~m}^{3} \mathrm{~s}^{-1}$} \\
\hline$\Delta \operatorname{SSL}\left(\mathrm{kg} \mathrm{s}^{-1}\right)$ & 6.5 & 2.0 & 5.0 & 13.5 \\
\hline $\operatorname{SSR}(\%)$ & 22.9 & 20.8 & 19.8 & 21.35 \\
\hline $\operatorname{TSR}(\%)$ & 61.46 & 60.42 & 59.90 & 60.68 \\
\hline \multicolumn{5}{|c|}{ 08.07.2005, $Q_{0}=1650 \mathrm{~m}^{3} \mathrm{~s}^{-1}$} \\
\hline$\Delta \mathrm{SSL}\left(\mathrm{kg} \mathrm{s}^{-1}\right)$ & 1.8 & 1.6 & 6.8 & 10.2 \\
\hline $\operatorname{SSR}(\%)$ & 10.3 & 19.1 & 29.4 & 20.71 \\
\hline $\operatorname{TSR}(\%)$ & 55.15 & 59.56 & 64.71 & 60.35 \\
\hline \multicolumn{5}{|c|}{ 15.08.2007, $Q_{0}=730 \mathrm{~m}^{3} \mathrm{~s}^{-1}$} \\
\hline$\Delta \mathrm{SSL}\left(\mathrm{kg} \mathrm{s}^{-1}\right)$ & 0.8 & 0.4 & 0.1 & 1.3 \\
\hline $\operatorname{SSR}(\%)$ & 15.0 & 20.0 & 2.5 & 10.03 \\
\hline $\operatorname{TSR}(\%)$ & 57.50 & 60.00 & 51.25 & 55.01 \\
\hline \multicolumn{5}{|c|}{ 08.09.2010, $Q_{0}=983 \mathrm{~m}^{3} \mathrm{~s}^{-1}$} \\
\hline$\Delta \operatorname{SSL}\left(\mathrm{kg} \mathrm{s}^{-1}\right)$ & 1.53 & 0.65 & 2.54 & 4.73 \\
\hline $\operatorname{SSR}(\%)$ & 21.4 & 42.9 & 50.0 & 34.36 \\
\hline $\operatorname{TSR}(\%)$ & 60.7 & 71.4 & 75.0 & 67.1 \\
\hline \multicolumn{5}{|c|}{ 21.07.2013, $Q_{0}=1482 \mathrm{~m}^{3} \mathrm{~s}^{-1}$} \\
\hline$\Delta \operatorname{SSL}\left(\mathrm{kg} \mathrm{s}^{-1}\right)$ & 3.0 & 1.1 & 0.6 & 4.7 \\
\hline $\operatorname{SSR}(\%)$ & 20.8 & 22.9 & 6.3 & 16.64 \\
\hline TSR $(\%)$ & 60.42 & 61.46 & 53.13 & 58.32 \\
\hline \multicolumn{5}{|c|}{ 20.07.2015, $Q_{0}=706 \mathrm{~m}^{3} \mathrm{~s}^{-1}$} \\
\hline$\Delta \operatorname{SSL}\left(\mathrm{kg} \mathrm{s}^{-1}\right)$ & 0.0 & -0.1 & -0.8 & -1.0 \\
\hline SSR $(\%)$ & 0.0 & -8.3 & -25.0 & -12.55 \\
\hline TSR (\%) & 50.00 & 45.83 & 37.50 & 43.73 \\
\hline
\end{tabular}

For both large channels (Lobanovskaja, Selenga (Kharauz), and Levobergnaja) and the smaller wetland-dominated channels (e.g., Sharokova and Shamanka) (see
Fig. 1), similar partitioning between metals in dissolved and suspended modes has been identified, with the exception of $\mathrm{Zn}$ and $\mathrm{Pb}$ that vary more. Considering the reaches 
where flow passes through wetland-dominated regions ("diffuse flow paths") (see SI) as opposed to flowing through large channels, strong retention effects can be seen as a pronounced decrease in total concentrations. In absolute concentration terms, retention decreased concentrations of key metals from around 6000 to $50 \mu \mathrm{g} 1^{-1}(\mathrm{Al})$ and from around 5000 to $1000 \mu \mathrm{g} 1^{-1}(\mathrm{Fe})$. Considering the relative retention, most metals show high retention from the upstream reach to the downstream delta edge along the sampled small channel, e.g., along Sredniy Peremoy channel in $2012 \mathrm{Al}(99 \%), \mathrm{Cd}(90 \%), \mathrm{Cr}(89 \%), \mathrm{Cu}$ (91\%), Pb (97\%), and $\mathrm{Zn} \mathrm{(91 \% );} \mathrm{for} \mathrm{the} \mathrm{Shamanka}$ channel system in 2013, retention is highest for $\mathrm{Al}(97 \%)$, $\mathrm{Cu}(99 \%), \mathrm{Fe}(95 \%)$, and Zn (85\%) (see SI). Among key metals, no retention in "diffuse flow paths" has been found for $\mathrm{As}$ in 2012 and $\mathrm{Pb}$ and $\mathrm{V}$ in 2013.

Longitudinal metals retention could be seen in bottom sediments contamination (see SI). The areas of highest metal concentrations are located within central part of the delta and are associated with the smallest flow paths. A doubling of $\mathrm{Fe}$ concentrations (from 20,000 up to $40,000 \mathrm{mg} \mathrm{kg}^{-1}$ ) in bottom sediments in the downstream part of the delta and the same magnitude of increase for As (from 4 to $8 \mathrm{mg} \mathrm{kg}^{-1}$ ) are the most remarkable examples of change. In the case of As, the concentration in some sampling points exceeded the concentrations values of the upper continental crust from Rudnick and Gao (2003).

\section{Discussion}

\section{Possible hydrological drivers of delta evolution and mass balances}

Over the past 70 years, hydroclimatic changes in the region have had significant impact on river runoff (Törnqvist et al. 2014; Chalov et al. 2015; Karthe et al. 2015a). In combination with direct anthropogenic pressures, such as the artificial increase in Lake Baikal's level after the Irkutsk dam construction, this initiated a new regime of delta development. While reshaping Lake Baikal's shore, this also led to a evolution of the channel network within the Selenga River delta and caused flooding of large areas of the delta.

Mass balances within the delta are governed by physical processes, which also underpin geochemical barrier functions. The period between 1959 (Irkutsk dam construction) until the end of twentieth century is associated with increased sediment loads in the Selenga River (Potemkina 2011; Chalov et al. 2015), whereas later period is characterized by $2.5 \mathrm{Mt}^{\text {year }}{ }^{-1}$ of annual total sediment load (suspended and bed load) delivered to the Selenga River, which is almost half the value for the earlier period.
Increased sediment delivery to the delta in the second half of the twentieth century could explain the observed large sediment deposition, leading to aggradation and delta surface rise up to $0.7 \mathrm{~m}$ during $1952-1998$ (Fig. 2). This is also supported by the evidence that water partitioning among the bifurcating channel network of the Selenga River delta due to decreasing carrying capacity was sufficient to reduce shear stress below the capacity necessary to transport gravel. Specifically, where the channel split among third- and fourth-order bifurcations (where the firstorder channel is the main Selenga River channel at the delta apex), it is observed that gravel is terminated from the downstream dispersal system (Dong et al. 2016). This occurs due to the nonlinear reduction in shear stress associated with water partitioning among the channels. Thus, with the reduction in transport capacity, the gravel is no longer transported downstream and is instead deposited to the channel bed. In the long term, the net effect would be a channel bed aggradation due to the deposition of the coarsest sediment in the system and significant changes in the delta morphology with appearance of new gravel islands.

Declines in sediment concentrations along the channel due to stream bifurcation reflect deposition and channel storage of sand along the main branches (Table 2; Fig. 4). One morphodynamic explanation of the retention effects along delta is the impact of braiding intensity and decline in transport capacity and width/depth ratio increase (Chalov and Alexeevsky 2015). Elevated (up to $33 \%$ ) SSR occurred during high discharge periods when a pronounced sediment retention at local reaches could be observed (Fig. 6) due to flows entering delta wetlands (lakes), biofiltration processes, and channel water seepage. The absence (loss) of wetland-dominated flows caused by decline in water stages during low water periods explains the decrease in SSR (e.g., observed at 15.08.2007 and 20.07.2015 under lowest water discharges). Another explanation for the smaller rates of SSR during low water periods is the decline in channel erosion during low water periods, thus lowering available sediments and hence total sediment deposition in the dowstream part of the delta. Also, possible backwater effects in the downstream part of the delta distributaries, especially during high flows, could play a role for sediment deposition in the channel.

The average rise in the delta identified by the DEM analyses (72 cm during 55 years) (Fig. 2) was compared to the sediment retention rates revealed from satellite images (Table 2; Fig. 4). Considering that the annual total sediment load (suspended load and bed load) delivered to the Selenga River Delta is $2.5 \mathrm{Mt}^{\text {year }^{-1}}$ (Potemkina 2011; Chalov et al. 2015), and that the delta area is $600 \mathrm{~km}^{2}$ with a total sediment retention TSR up to $67 \%$ (Table 2), and assuming also a sediment density of $1700 \mathrm{~kg} \mathrm{~m}^{-3}$ 
(Alexeevsky et al. 2013), we estimated an accumulation rate over delta, based on the sediment retention. It was found that $20 \mathrm{~cm}$ of the total delta elevation increase during 55 years $(0.36 \mathrm{~cm}$ per year $)$ is explained by sediment load retention. It could hence only partly account for the mentioned delta rise based on DEM. More sediment is needed to feed the delta as far as the rise of $72 \mathrm{~cm}$ identified by DEM analysis is higher than these $20 \mathrm{~cm}$. Partly, this additional sediment amount could be related to bank erosion in the delta topset. Tectonic lift effects (Logachev 2003) and DEM uncertainties should also be also considered.

The decline in sediment delivery since 1995 might profoundly change the delta morphology and reduce the sediment retention along delta (Table 2). In particular, this is because up to $90 \%$ of the total (bed and suspended) annual sediment load in the region and almost all bed load transport (particularly sand and gravel) occur under flood conditions (Chalov et al. 2015), whereas the magnitude of the floods over the last 20 years declined to almost half of their previous levels (Törnqvist et al. 2014). According to Potemkina and Fialkov (1993), up to $90 \%$ of the sediment delivered to delta was trapped during floods in the early 1980 s, whereas during the low water period, this value reached $50 \%$ of the total sediment load (bedload and suspended load). Total sediment trapping in the recent period (since 1989) varies between 50 and $60 \%$ in the left sector and 37 and $76 \%$ in the right sector according to the present results.

Changes in the delta hydrology and associated barrier functions are related to the fast changing delta landscape under the new hydroclimatic conditions. Expected future declines of the Selenga River discharge due to reservoir constructions in Mongolia could have a significant impact on the barrier function of the delta. On one side, sedimentation in the reservoirs could decrease the total amount of sediments reaching the delta. On the other hand, expected decline in water runoff and water stages will lead to the abandonment of wetland-dominated areas which at present can sequester (filter) significant part of the suspended sediment flow through the delta. These effects were observed during extreme low water conditions in the summer of 2015, when the deltaic wetlands lost a significant part of the stream network, there was little overbank flow into the ponds, and most of the water and sediments were conveyed through the large channels directly into Lake Baikal (Table 2).

The hydroclimatic decline in sediment yield supplied to the Selenga River delta is an order of magnitude larger than for many rivers experiencing considerable human pressures, such as the Mississippi River (Nittrouer et al. 2011) that still provides a sufficient amount of sand into its delta. In the near future, this decline could be even sharper due to hydrological changes in the Selenga River Basin. Due to land-use changes (Karthe et al. 2015b, Priess et al. 2011), the impacts of global climate change on precipitation, evaporation, and distribution of permafrost (Törnqvist et al. 2014), and increasing water withdrawals by anthropogenic activities (expansion of agriculture and rising irrigation needs in the context of global warming (Priess et al. 2011), water diversions into mining areas of the South Gobi (Sorokovikova et al. 2013) and dams in the Selenga River main stem) further decrease in flood magnitude could be expected, thus leading even to more drastic change in sediment loads in the downstream Selenga River.

The calculated proportions of $17-35 \%$ of suspended sediment load storage within the Selenga River delta are consistent with storages calculated for other world deltas, which vary between $16 \%$ (e.g., Po River delta, Italy; Syvitski et al. 2005) and $47 \%$ (e.g., Yangtze River delta, China; Liu et al. 2007). The natural storage processes in the Selenga River delta are also influenced by the anthropogenic intra-annual water-level changes in Lake Baikal with an average recent amplitude of $1 \mathrm{~m}$ (maximum levels in October and minimum in May; The Baikal Basin Information Centre 2015). Similar changes in water levels (e.g., tides or see level rise) can have a significant impact on spatial changes in observed SSC and erosion-deposition processes in river mouths (Postma 1995; Gernez et al. 2015).

The average decline of SSC in the transient zone from river to the receiving basin (ocean or lake) varies (Lisitzin 1995) from $83 \%$ (rivers of Black sea coast) to $90 \%$ (Mississippi River) and $95 \%$ (Amazon, Yellow river). In case of the Selenga River, the reported SSC increase in the South Basin of Lake Baikal due to terrigenous input from the Selenga River during storm events was up to $2 \mathrm{mg} \mathrm{l}^{-1}$ in early July 2001 (Heim et al. 2005, assessed by SeaWiFS satellite data). Considering baseline values in Lake Baikal as $0.5 \mathrm{mg} \mathrm{l}^{-1}$ and taking into account the values of longitudinal SSC decrease up to $50 \%$ the delta, sediment retention in the delta explains up to $50 \%$ of the total sediment decline on the interface between the river system and Lake Baikal.

\section{Spatial distribution of sediment and metals patterns}

The largest decrease in sediment and metal concentrations occurred in the wetland-dominated areas of the delta. Many small flow paths in the near-lake downstream edge encounter small lakes and ponds which significantly increase the sediment retention. These diffuse channel systems show a consistent pattern of considerable metals filtering and thus removal from the dispersal system, associated with sediment retention during high-flow conditions and other processes (mostly biofiltration) during 

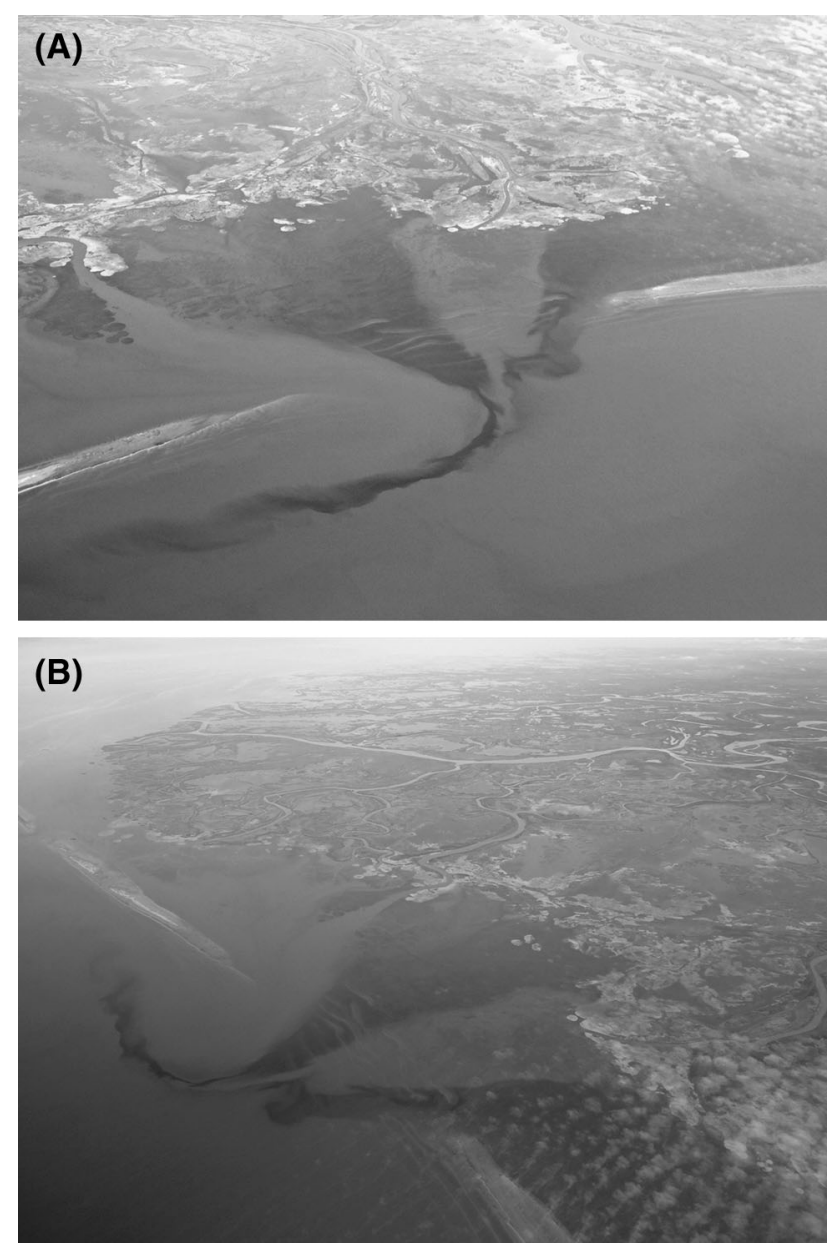

Fig. 5 Examples of the plumes at the exit of the various flow paths to Baikal Lake (photograph by authors from ULM, 2012-2013)

low-flow conditions. For the larger channels, the direct measurements provide evidence that turbidity and metal concentrations can at times be at constant levels along full reaches of the main channels, and also at times exhibit increasing concentrations near the downstream channel outlets. This may explain why plumes of high suspended sediment concentration are occasionally observed exiting the delta through the main channels (Fig. 5). In some cases, other controls could play a dominant role in metal concentrations. For instance, $\mathrm{Fe}$ is controlled by redox potential, being oxidized at the geochemical river/lake barrier and removed as undissolved hydroxide from the lake water. Additionally, its concentration in the water of wetlands sharply increases because of oxygen deficiency, especially in the winter (Chebykin et al. 2012).

Average metal concentrations in the delta were observed to be relatively high under low-flow conditions. However, the mass flow of sediments and metals is by definition equal to the product between element concentration and water flow. Therefore, the differences in mass flows between high water conditions and low water conditions were suppressed, since total turbidity and metal concentrations increased as water flow decreased. This mechanism tends to reduce the temporal variability in mass flows of sediments and contaminants entering Lake Baikal. More generally, this indicates conditions of supply limitation.

The partitioning of metals between dissolved and suspended phases influences both the mobility and toxicity of metals and is thus of relevance for the hydrological transport of metals through the Selenga River delta system to Lake Baikal. The total metal concentrations are dominated by suspended forms of metals and the dissolved forms make up a minor part of the mass, which is in line with previous quantifications in this region (Thorslund et al. 2012; Chalov et al. 2015). Furthermore, a comparison of the partitioning of key metals $(\mathrm{Al}, \mathrm{Fe}, \mathrm{Pb}$, and $\mathrm{Zn})$ in the here considered downstream delta region, with the upstream Tuul River region (both within the Selenga River basin), shows that average partitioning of these metals for the snapshot measurements in 2013 is not that different. The distribution from the upstream river to the downstream delta does not change more than up to $10 \%$, with the downstream region showing higher fractions of metals in suspended forms compared to the upstream location (Pietron et al. 2015). This indicates that geochemical processes that govern the partitioning of these metals might be similar over large distances (between upstream pollution source zones and the downstream delta). Given that the retention function is highest for metals in suspension, prevailing geochemical conditions may thus favor efficient metal removal of the smaller channels of the delta. The mass fractions of removed contaminants in the small channels are relatively similar regardless of the absolute mass flow entering the delta, which suggests that the current trend of decreased sediment inputs to the delta results in decreased outputs into Lake Baikal in terms of sediment and contaminant mass flows.

The significant role of diffuse flows through small channels and wetlands in sediment and metal retention is explained by lower flow velocities enabling gravitational sedimentation and role of water plants in bioaccumulation. More generally, a considerable amount of aquatic plants grow in the delta because of its favorable conditions, and these plants cover up to $20 \%$ of the water bodies (Akhtman et al. 2014) during the low water period (vegetation consists mostly of small yellow pond lily and floating heart, pondweeds and watermilfoils). In the end of the vegetation period, the main aquatic species in the delta can accumulate from 1.5 to $30.5 \%$ of incoming metals (Akhtman et al. 2014).

The barrier functions of the delta are closely dependent on the seasonal flow variability in the certain distributaries. 


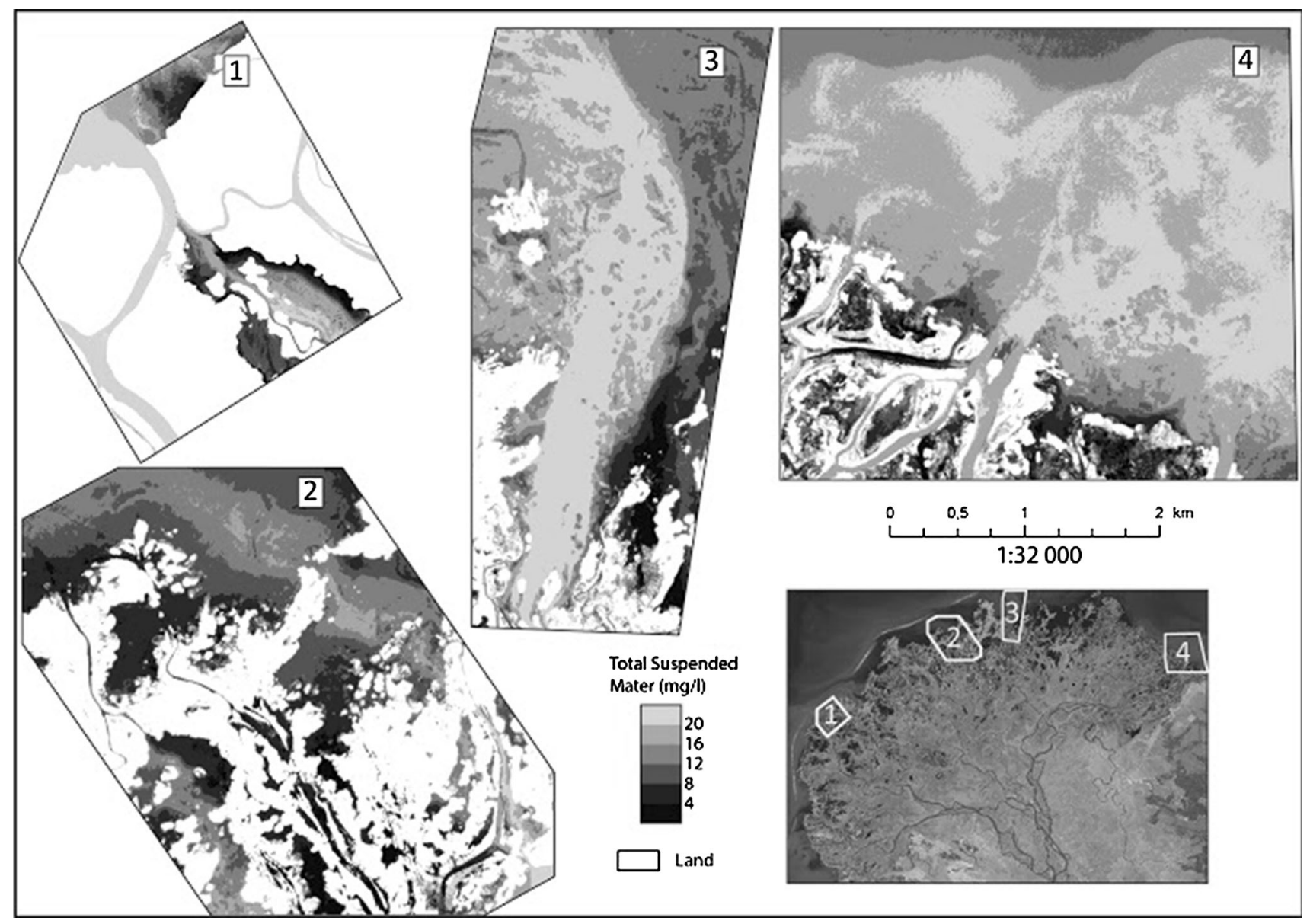

Fig. 6 Large-scaled buffer zones of sediment transport in near-lake part of the Selenga River delta (maps constructed based on data from ULM imagery)

As far as more water is conveyed (up to $40 \%$ of the total flow) under low-flow conditions to the left sector (Fig. 3; Table 1), it is inevitable have an impact on sediment and metal transport and storage establishing more transient mode of sediments dispersal. In opposite, more water is conveyed through wetlands in right sector due to general patterns of flow partitioning, and thus increasing the capability to store supplied sediments. This could be seen in the significant decrease in SSC along the channels located in central and right sectors (II and III) and in the highly complex flow regime in the right and central distributaries, which is due to larger inundation of the riparian area in comparison with the left sector (Fig. 6).

Taken together, the observed spatiotemporal dynamics of the Selenga River delta emphasizes the role of wetlands in filtering the discharge of metals into Lake Baikal. In areas between main channels where flows are diffuse, the mass reduction in key metals such as $\mathrm{Al}, \mathrm{Cu}, \mathrm{Fe}, \mathrm{Pb}$, and $\mathrm{Zn}$ was shown to range between 77 and $99.8 \%$. Since the mass reduction in the main channels was considerably smaller or nonexistent, the overall performance of the delta as a barrier for pollution flows may to a large extent depend on the amount of flow passing through the system of small channels relative to the amount passing through the main channels. This is consistent with findings in Quin et al. (2015), who showed that on landscape scales, the efficiency of pollutant retention is governed by the fraction of the total runoff that intersects wetland areas. Measurements indicate that approximately $20-30 \%$ of the total flow in the central and right sectors and only 5-10\% in the left sector will pass extensive wetland areas associated with small channels, which hence determines the filtering function of the delta, in terms of the removed mass fraction of sediments and metals, and then explains the increase (up to $50 \%$ ) in the mass retention in the right distributaries in comparison with the left (up to $20 \%$ ).

\section{Conclusions}

The Selenga River delta provides an outlet geochemical barrier that protects Lake Baikal waters from sediment and metals delivered from the Selenga River catchment. The present study provides an overview of processes in delta 
areas, which are naturally located in the intersection between upstream rivers and their downstream recipients:

1. In a period of approximately five decades, sediment storage has contributed to a surface elevation rise of up to $0.7 \mathrm{~m}$ in the Selenga River delta. Up to $30-40 \%$ of the suspended load and $70 \%$ of the total sediment load are stored in the delta. The role of different delta distributary systems in sediment retention depends on the changes in delta morphology and flow partitioning, which in particular was characterized by a discharge increase in the left sector, by up to $45 \%$ relative to the total summer flow, and $30 \%$ during the floods.

2. The delta network has a large influence on the mass of metals reaching Lake Baikal at the delta outlet. There is a pronounced decrease in total concentrations along the smaller flow paths that pass through wetland regions, with the relative retentions reaching or exceeding $90 \%$ for $\mathrm{Al}, \mathrm{Cd}, \mathrm{Cu}, \mathrm{Pb}$, and $\mathrm{Zn}$ ). This is accompanied by a concentration increase in the bottom sediments in the downstream part of the delta.

Changing environmental conditions (due to climate change and anthropogenic impacts) have led to changing flow regimes in the Selenga River delta. These changes have profound effects on sediment and metal retention and delivery to Lake Baikal. Because of limited datasets and considerable scientific complexity, many areas of uncertainty remain concerning sediment and metal transport in the Selenga River delta, emphasizing the need of further process studies. These are a prerequisite for planning river basin management (e.g., Karthe et al. 2015c) even in areas far upstream.

Acknowledgments This research was conducted within the project of Russian Scientific Foundation No. 14-27-00083, and the project of the Swedish Research Council Formas (Project Number 2012-790). The field research and communication between the co-authors (workshops) was additionally funded by the following projects: Russian Fund for Basic Research Project No. 15-05-05515; Russian Geographical Society Project "Expedition Selenga-Baikal"; BMBFIB project "WQQ Selenga-Baikal-Modelling of Water Quantity and Quality in the Selenga-Baikal-Angara Region: Current Potentials and Future Necessities" (Grant Number 01DJ14013); PEOPLE MARIE CURIE ACTIONS International Research Staff Exchange Scheme Call: FP7-PEOPLE-2012-IRSES "Fluvial processes and sediment dynamics of slope channel systems: Impacts of socioeconomic and climate change on river system characteristics and related services."

\section{References}

Ajao EA, Anurigwo S (2002) Land-based sources of pollution in the Niger Delta, Nigeria. Ambio 31:442-445. doi:10.1579/00447447-31.5.442
Akhtman Y, Constantin D, Rehak M, Nouchi V, Shinkareva G, Bouffard D, Pasche N, Chalov S, Lemmin U, Merminod B (2014) Télédétection multi-échelle des lacs depuis un aéronef ultraléger motorisé. Géomatique Suisse 9:395-398

Alexeevsky NI, Chalov RS, Berkovich KM, Chalov SR (2013) Channel changes in largest Russian rivers: natural and anthropogenic effects. Int J River Basin Manag 11(2):75-191. doi:10. 1080/15715124.2013.814660

Aynbund MM, Davtyan NA, Sudolsky AS, Fialkov VA (1975) Research of rivers mouths dynamics and delta sites of water reservoirs on the example of the Selenga River and the lake Baikal In: Proceedings of IV Vsesoyuz. Hydr. Congress. Hydrology of lakes, reservoirs and mouths of the rivers, vol 5, pp 356-365

Brumbaugh WG, Tillitt DE, May TW, Javzan CH, Komov VT (2013) Environmental survey in the Tuul and Orkhon river basins of northcentral Mongolia, 2010: metals and other elements in streambed sediment and floodplain soil. Environ Monit Assess 185:8991-9008. doi:10.1007/s10661-013-3229-9

Buschmann J, Berg M, Stegel C, Sampson M (2007) Arsenic and manganese contamination of drinking water resources in Cambodia: coincidence of risk areas with low relief topography. Environ Sci Technol 41(7):2146-2152. doi:10.1021/es062056k

Chalov SR, Alexeevsky NI (2015) Braided rivers: structure, types and hydrological effects. Hydrol Res 46(2):258-275. doi:10.2166/nh. 2013.023

Chalov SR, Zavadsky AS, Belozerova EV, Bulacheva MP, Jarsjo J, Thorslund J, Yamkhin J (2012) Suspended and dissolved matter fluxes in the upper Selenga River Basin. Geogr Environ Sustain 5(2):78-94

Chalov SR, Kasimov N, Lychagin M, Alexeevsky N, Belozerova E, Theuring P, Shinkareva G, Romanchenko A, Garmaev E (2013) Water resources assessment of the Selenga-Baikal river system. GeoÖko 34:77-102

Chalov SR, Jarsjö J, Kasimov N, Romanchenko A, Pietron J, Thorslund J, Belozerova E (2015) Spatio-temporal variation of sediment transport in the Selenga River Basin, Mongolia and Russia. Environ Earth Sci 72(2):663-680. doi:10.1007/s12665014-3106-z

Chatterjee M, Massolo S, Sarkar SK, Bhattacharya AK, Bhattacharya BD, Satpathy KK, Saha S (2009) An assessment of trace element contamination in intertidal sediment cores of Sunderban mangrove wetland, India for evaluating sediment quality guidelines. Environ Monit Assess 150(1-4):307-322. doi:10.1007/s10661008-0232-7

Chebykin E, Goldberg E, Kulikova N (2010) Elemental composition of suspended particles from the surface waters of Lake Baikal in the zone affected by the Selenga River. Russ Geol Geophy 51(10):1126-1132

Chebykin E, Sorokovikova L, Tomberg I, Rasskazov S, Khodzher T, Grachev M (2012) Current state of the Selenga River waters in the Russian territory concerning major components and trace elements. Chem Sustain Dev 20(5):561-580

Dong TY, Nittrouer JA, Il'icheva E, Pavlov M, McElroy B, Czapiga MJ, Ma H, Parker G (2016) Controls on gravel termination in seven distributary channels of the Selenga River Delta, Baikal Rift basin, Russia. Geol Soc Am Bull. doi:10.1130/B31427.1

Doxaran D, Froidefond JM, Lavender S, Castaing P (2002) Spectral signature of highly turbid waters. Application with SPOT data to quantify suspended sediment matter concentrations. Remote Sens Environ 81:149-161. doi:10.1016/S0034-4257(01)00341-8

Garmaev EJ, Khristoforov AV (2010) Water resources of the rivers of the Lake Baikal Basin: basics of their use and protection. Geo, Novosibirsk

Gernez P, Lafon V, Lerouxel A, Curti C, Lubac B, Cerisier S, Barillé L (2015) Toward Sentinel-2 high resolution remote sensing of 
suspended particulate matter in very turbid waters: SPOT4 (Take5) experiment in the Loire and Gironde estuaries. Remote Sens 7(8):9507-9528. doi:10.3390/rs70809507

Heim B, Oberhaensli H, Fietz S, Kaufmann H (2005) Variation in Lake Baikal's phytoplankton distribution and fluvial input assessed by SeaWiFS satellite data. Global Planet Change 46:9-27. doi:10.1016/j.gloplacha.2004.11.011

Ilyicheva EA (2008) Dynamics of structure of a river network of the Selenga River and its delta. Geogr Nat Resour 4:58-63. doi:10. 1016/j.gnr.2008.10.011

Inam E, Khantotong S, Kim KW, Tumendemberel B, Erdenetsetseg S, Puntsag T (2011) Geochemical distribution of trace element concentrations in the vicinity of Boroo gold mine, Selenge Province, Mongolia. Environ Geochem Health 33:57-69. doi:10. 1007/s10653-010-9347-1

Karthe D, Chalov S, Borchardt D (2015a) Water resources and their management in Central Asia in the early 21st century: status, challenges and future prospects. Environ Earth Sci 73(2):487-499. doi:10.1007/s12665-014-3789-1

Karthe D, Heldt S, Houdret A, Borchardt D (2015b) IWRM in a country under rapid transition: lessons learnt from the Kharaa River Basin, Mongolia. Environ Earth Sci 73(2):681-695. doi:10.1007/s12665-014-3435-y

Karthe D, Hofmann J, Ibisch R, Heldt S, Westphal K, Menzel L, Avlyush S, Malsy M (2015c) Science-based IWRM implementation in a data-scarce central Asian region: experiences from a research and development project in the Kharaa River Basin, Mongolia. Water 7(7):3486-3514. doi:10.3390/w7073486

Lisitzin AP (1995) The marginal filter of the ocean. Oceanology 34:671-682

Liu JP, Xu KH, Li AC, Milliman JD, Velozzia DM, Xiao SB, Yange AC (2007) Flux and fate of Yangtze River sediment delivered to the East China, Sea. Geomorphology 85(3):208-224. doi:10. 1016/j.geomorph.2006.03.023

Logachev NA (2003) History and geodynamics of the Baikal rift. Russ Geol Geophys 44(5):391-406

Lychagin MY, Tkachenko AN, Kasimov NS, Kroonenberg S (2015) Heavy metals in the water, plants, and bottom sediments of the Volga River mouth area. J Coast Res 31(4):859-868. doi:10. 2112/jcoastres-d-12-00194.1

Meybeck M, Vörösmarty C (2005) Fluvial filtering of land-to-ocean fluxes: from natural Holocene variations to Anthropocene. CR Geosci 337(1):107-123. doi:10.1016/j.crte.2004.09.016

Nadmitov B, Hong S, Kang SI, Chu JM, Gomboev B, Janchivdorj L, Lee CH, Khim JS (2014) Large-scale monitoring and assessment of metal contamination in surface water of the Selenga River Basin (2007-2009). Environ Sci Pollut Res 22(4):2856-2867. doi:10.1007/s11356-014-3564-6

Nittrouer JA, Mohrig D, Allison MA (2011) Punctuated sand transport in the lowermost Mississippi River. J Geophys Res 116:1-24. doi:10.1029/2011JF002026

Perel'man AI (1986) Geochemical barriers: theory and practical applications. Appl Geochem 1(6):669-680. doi:10.1016/08832927(86)90088-0

Pfeiffer M, Batbayar G, Hofmann J, Siegfried K, Karthe D, HahnTomer S (2015) Investigating arsenic (As) occurrence and sources in ground, surface, waste and drinking water in northern Mongolia. Environ Earth Sci 73(2):649-662. doi:10.1007/ s12665-013-3029-0)

Pietroń J, Jarsjö J, Romanchenko A, Chalov SR (2015) Model analyses of the contribution of in-channel processes to sediment concentration hysteresis loops. J Hydrol 527:576-589. doi:10. 1016/j.jhydrol.2015.05.009
Postma G (1995) Sea-level-related architectural trends in coarsegrained delta complexes. Sediment Geol 98(1):3-12. doi:10. 1016/0037-0738(95)00024-3

Potemkina TG (1995) Distribution of Water and Sediment Runoff in the Selenga Delta Branches. Geografiya i prirod. resursy 1:75-78

Potemkina TG (2011) Sediment runoff formation trends of major tributaries of Lake Baikal in the 20th century and at the beginning of the 21st century. Russ Meteorol Hydrol 36(12):819-825. doi:10.3103/S1068373911120077

Potemkina TG, Fialkov VA (1993) The balance of suspended load in Selenga Delta and its distribution in Lake Baikal. Water Resour 20:689-692

Priess J, Schweitzer C, Wimmer F, Batkhishig O, Mimler M (2011) The consequences of land-use change and water demands in Central Mongolia. Land Use Policy 28(1):4-10. doi:10.1016/j. landusepol.2010.03.002

Quin A, Jaramillo F, Destouni G (2015) Dissecting the ecosystem service of large-scale pollutant retention: the role of wetlands and other landscape features. Ambio 44(Suppl. 1):127-137. doi:10.1007/s13280-014-0594-8

Rudnick RL, Gao S (2003) Composition of the continental crust. In: Treatise on geochemistry. The Crust. Elsevier Science 3:1-64. doi: 10.1016/B0-08-043751-6/03016-4

Santschi PH, Presley BJ, Wade TL, Garcia-Romero B, Baskaran M (2001) Historical contamination of PAHs, PCBs, DDTs, and heavy metals in Mississippi River Delta, Galveston Bay and Tampa Bay sediment cores. Marine Environ Res 52:51-79. doi:10.1016/S0141-1136(00)00260-9

Shaban M, Urban B, El Saadi A, Faisal M (2010) Detection and mapping of water pollution variation in the Nile Delta using multivariate clustering and GIS techniques. J Environ Manage 91(8):1785-1793. doi:10.1016/j.jenvman.2010.03.020

Sholkovitz ER (1976) Flocculation of dissolved organic and inorganic matter during the mixing of river water and seawater. Geochim Cosmochim Acta 40:831-845. doi:10.1016/0016-7037(76)90035-1

Sorokovikova LM, Popovskaya GI, Tomberg IV, Sinyukovich VN, Kravchenko OS, Marinaite II, Bashenkhaeva NV, Khodzher TV (2013) The Selenga River water quality on the border with Mongolia at the beginning of the 21st century. Russ Meteorol Hydrol 38(2):126-133. doi:10.3103/S1068373913020106

Stubblefield A, Chandra S, Eagan S, Tuvshinjargal D, Davaadorzh G, Gilroy D, Sampson J, Thorne J, Allen B, Hogan Z (2005) Impacts of gold mining and land use alterations on the water quality of central Mongolian rivers. Integr Environ Assess Manag 1:365-373

Syvitski JP, Kettner AJ, Correggiari A, Nelson BW (2005) Distributary channels and their impact on sediment dispersal. Mar Geol 222:75-94. doi:10.1016/j.margeo.2005.06.030

The Baikal Basin Information Centre (2015) State of the environment report, The Lake Baikal Basin. (Web. pdf) Accessed 25 Aug 2015

Thorslund J, Jarsjö J, Belozerova E, Chalov S (2012) Assessment of the gold mining impact on riverine heavy metal transport in a sparsely monitored region: the upper Lake Baikal Basin case. J Environ Monit 14:2780-2792. doi:10.1039/c2em30643c

Thorslund J, Jarsjö J, Wällstedt T, Mörth CM, Lychagin MY, Chalov SR (2016) Speciation and hydrological transport of metals in a non-acidic river system: field data and model predictions. Reg Environ Change. doi:10.1007/s10113-016-0982-7

Törnqvist R, Jarsjö J, Pietron J, Bring A, Rogberg P, Asokan SM, Destouni G (2014) Evolution of the hydro-climate system in the Lake Baikal basin. J Hydrol 519:1953-1962. doi:10.1016/j. jhydrol.2014.09.074 